\title{
The Effect of Jajar Legowo Planting System on Ciherang Paddy Varieties
}

\section{Darwati Susilastuti*, Aditiameri, and Ubuh Buchori}

Faculty of Agriculture, Borobudur University, Jakarta, Indonesia

*Email address: darwatisusi@borobudur.ac.id

\begin{abstract}
Intensification on paddy is done one of them by setting the spacing. This study aims to examine the effect of spacing system on growth and paddy production. The research was conducted in Bojongmangu Village, Bekasi Regency, West Java Province. The study used an experimental method Randomized Completely Block Design (RCBD) with 1 factor that is planting system, namely tegel system 20 $\mathrm{cm} \times 20 \mathrm{~cm}$, tegel system $25 \mathrm{~cm} \times 25 \mathrm{~cm}$, jajar legowo 2:1 $(25 \times 12,5 \times 50) \mathrm{cm}$, jajar legowo 4:1 full $(25 \times 12,5 \times 50$ ) $\mathrm{cm}$, jajar legowo $4: 1$ free space $(25 \times 12,5 \times 50) \mathrm{cm}$, and jajar legowo $6: 1(25 \times 12,5 \times 50) \mathrm{cm}$. Each treatment is repeated 3 times. The results showed that jajar legowo planting system 2:1 gives the number of panicles per clump, number of grains per panicle, weight of 1000 grains and the average yield per hectare is highest, followed by jajar legowo 4:1 full planting system.
\end{abstract}

Keywords: Jajar Legowo, Planting System Citation to this paper should be made as follows:

Susilastuti, D., Aditiameri, and U. Buchori. 2018. The Effect of Jajar Legowo Planting System on Ciherang Paddy Varieties. Agritropica: Journal of Agricultural Science. 1 (1): 1-8.

DOI : https://doi.org/10.31186/J.Agritropica.1.1.1-8

\section{INTRODUCTION}

In Indonesia, rice consumption from year to year continues to increase in line with the increasing rate of population growth. On the other hand, there is the conversion of wetland to non-agricultural such as residential complexes, shops, industrial areas, among others, especially in Java and Bali. This phenomenon will enlarge the food problem. For food security, the conversion of paddy fields is a serious threat because of its permanent and negative impacts on rice production. According to BPS (2018), average Indonesian rice consumption reached 1.571 $\mathrm{kg} /$ capita/week. BPS (2018) also reported that by 2017, the national paddy area reaches $15,696,915 \mathrm{ha}$, the national production is $81,072,701$ tons and the average productivity is 5.165 tons/ha. Meanwhile, the import of rice in 2018 reaches 500 thousand tons (Sari, 2018).

One effort to increase the productivity of paddy plants is optimizing the population of plants per hectare through planting distance arrangement, known as Jajar Legowo planting system. The Jajar Legowo planting system is a pattern of planting that alternates between two or more (generally two or four) crop lines and one free space row. Thus, it will obtain an optimal growing space for the growth and development of plants, facilitate the conduct of the treatment plants, create a sub-optimal environment for the plant-disturbing organism and increase the population of more than 160,000 plants per hectare (Sarlan et al, 2013). In addition, the plants on the edge grow and develop better and the yield per clump is higher than that of the middle plants. This indicates that the more border side bordering plants in the paddy fields produce more grain, much because in this system there is open space of $25 \%-50 \%$. The plant will receive sunlight optimally useful in the process of photosynthesis (Ikhwan et al, 2013). Setting the planting system determines the quantity and quality of the paddy clump, which then with the population/number of plant clumps per unit area affect the crop yield. 
Some research results related to the spacing arrangement is done by Meas et al. (2011). They found that the spacing of $20 \times 20$ $\mathrm{cm}$ planting density gives the best result with uptake TN $94.8 \mathrm{~kg} / \mathrm{ha}$ and $29.9 \mathrm{~kg} /$ ha for $\mathrm{P}$ in Korea. Plant spacing of $20 \times 35$ legowo planting system gives the best result in Minahasa (Karokaro et al., 2015). A research Legowo planting system 2:1 yielded 6.08 ton per ha and was best treatment giving highest yield in Subang Indonesia (Kusyaeri et al., 2014). The report on Legowo apllication in Bajeng subdistrict, Gowa regency in technical irrigation paddy field showed dry grain yield reach $8.50 \mathrm{t}$ / ha higher than tegel (Java language) system of $6.36 \mathrm{t} / \mathrm{ha}$ (Sarlan A. et al 2013). Plant spacing on the jajar legowo base of $25 \mathrm{~cm}$ has been provided more number of productive tillers than that of $21 \mathrm{~cm}$ (Hatta, 2012). The best results for a number of productive tillers, the average production of grain/plot, weight of 1000 grain was in the treatment plant system Legowo row 2:1 (Sari, 2014; Darmawan, 2016). The participation level of use Legowo system affected by economic characteristics, age, education, land and frequency following extension (Mulyati et al., 2017).

The effect of legowo row planting system application on paddy field has not been consistent, therefore further study is needed. This study aims to examine the influence of 6 (six) types of planting system to growth and yield of Ciherang paddy varieties.

\section{RESEARCH METHOD}

The research was conducted from March 2017 to July 2017 in the area of Bojongmagu village, Bekasi Regency of West Java Province. Elevation of the place about 95 $\mathrm{m}$ above sea level and based on 10-year rainfall data (2006 - 2015) the experimental location is included in C (slightly wet) climate type according to Schmidt \& Ferguson climate classification. The temperature average ranges from $28-32^{\circ}$ C. Red yellow podzolic soil type with $\mathrm{pH}$ 5. 2.

The materials used are Ciherang variety certified seeds, fertilizer, carbofuran insecticides and other raw materials (adjusted with the attacking pest type), fungicides, and herbicides. The study used an experimental method with Randomized Completely Block Design (RCBD) with1 factor i.e planting system, namely $\mathrm{T} 1=$ tile system $20 \mathrm{~cm} \times 20 \mathrm{~cm}$, $\mathrm{T} 2$ = tile system $25 \mathrm{~cm} \times 25 \mathrm{~cm}$; T3 = jajar legowo 2: $1(25 \times 12,5 \times 50) \mathrm{cm}$ (Figure 1); $\mathrm{T} 4=$ jajar legowo 4:1 full $(25 \times 12,5 \times 50) \mathrm{cm}$ (Figure 2); T5 = jajar legowo 4:1 free space $(25 \times 12,5 \times 50) \mathrm{cm}$ (Figure 3); T6 = jajar legowo 6: $1(25 \times 12,5 \times 50) \mathrm{cm}$ to obtain 6 (six) types of spacing system (Table 1). Each treatment is repeated 3 replications and each replication consists of 6 plant samples.

\section{Table 1 Planting System Treatment}

\begin{tabular}{clc}
\hline $\begin{array}{c}\text { Treatment } \\
\text { Code }\end{array}$ & \multicolumn{1}{c}{$\begin{array}{c}\text { Planting System } \\
\text { Type }\end{array}$} & $\begin{array}{c}\text { Plant Population (clump } \\
\text { per plot) } \\
(2.5 \mathrm{mx} 2.5 \mathrm{~m})\end{array}$ \\
\hline T1 & Tegel $(20 \times 20) \mathrm{cm}$ & 156 \\
T2 & Tegel $(25 \times 25) \mathrm{cm}$ & 100 \\
T3 & Jajar Legowo $2: 1(25 \times 12,5 \times 50) \mathrm{cm}$ & 120 \\
T4 & Jajar Legowo $4: 1$ Full $(25 \times 12,5 \times 50) \mathrm{cm}$ & 160 \\
T5 & Jajar Legowo 4:1 Free Space $(25 \times 12,5 \times 50) \mathrm{cm}$ & 120 \\
T6 & Jajar Legowo 6:1 $(25 \times 12,5 \times 50) \mathrm{cm}$ & 160 \\
\hline
\end{tabular}

The experiment was initiated by tilling the soil twice, hoeing and trimming, then plot

experiments of $2.5 \mathrm{~m} \times 2.5 \mathrm{~m}$ in size, made of roving and transverse trenches to remove 
excess water. Then followed by soaking seed varieties aimed at softening the husks of grain in order to accelerate the seed germinating. Immersion is conducted for 48 hours. Nurseries are done in a shaded place until the seeds aged 17 days to then ready to be planted. Planting to field plot with two seeds per hole, planting system as follows:

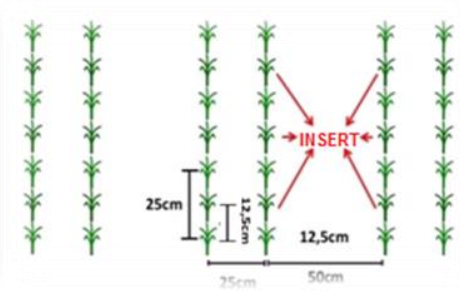

Jajar Legowo 2:1 Planting System

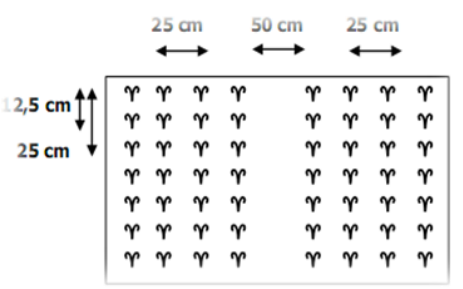

Jajar Legowo 4: 1 Full Planting System

\section{Figure 1 Jajar Legowo Planting System (Sarlam A. et al., 2013)}

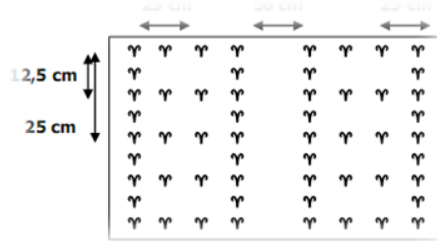

Jajar Legowo 4:1 Free Space System

Fertilizer application is done by evenly sown into the soil during wet season conditions, carried out the day before planting, 21 wap (week after planting), 34 wap. Harvesting is done when $95 \%$ of panicles have been yellowing in the experimental plot.

Parameter observations include: plant height, number of tillers, number of productive tillers, panicle length per clump, panicle length, number of grains per panicle, number of fully grains per panicle weight 1000 grains, weight of grain/plant, weight of fully grain per plant, percent of empty grain per plant, yield of plant per plot (ton/ha). The observed data were analyzed for its diversity using $\mathrm{F}$ test at 5\% level, followed by DMRT test at 5\% level.

\section{RESULT AND DISCUSSION}

\section{Plant Height and Number of Tillers}

Jajar Legowo 2:1 planting system using spacing $(25 \times 12.5 \times 50) \mathrm{cm}$ resulting in less plant per hectare population over 213.300 clumps per hectare, and will increase the plant population by $33.31 \%$ compared to the cropping pattern (25x25) cm which is only 160.000 clump/ha.

Planting system jajar legowo 4: 1 full which is a legowo planting pattern with the whole line got plant inserts with the plant spacing of $25 \mathrm{~cm} \times 12,5 \mathrm{~cm} \times 50 \mathrm{~cm}$ resulted in plant population reaching $\pm 256.000 \mathrm{clump} / \mathrm{ha}$ with the population increase of $60 \%$ compared to tegel pattern $(25 \times 25) \mathrm{cm}$.

Table 2. The Effect of Plant Spacing on Height and Number of Tillers of Ciherang Paddy Varieties

\begin{tabular}{lrrrrrr}
\hline \multirow{2}{*}{ Plant Spacing } & \multicolumn{3}{c}{ Plant height $(\mathbf{c m})$} & \multicolumn{2}{c}{ Number of tillers per clump } \\
\cline { 2 - 7 } & 4 WAP & 6 WAP & 8 WAP & 4 WAP & 6 WAP & 8 WAP \\
\hline T1 = tegel $(20 \times 20) \mathrm{cm}$ & $35.73 \mathrm{~b}$ & $67.67 \mathrm{a}$ & $80.00 \mathrm{a}$ & $13.00 \mathrm{a}$ & $30.53 \mathrm{a}$ & $32.87 \mathrm{a}$ \\
T2 = tegel $(25 \times 25)$ & $32.87 \mathrm{a}$ & $63.93 \mathrm{a}$ & $77.00 \mathrm{a}$ & $15.87 \mathrm{a}$ & $27.67 \mathrm{a}$ & $32.60 \mathrm{a}$ \\
T3 = legowo 2: $1(25 \times 12.5 \times 50) \mathrm{cm}$ & $34.60 \mathrm{a}$ & $63.80 \mathrm{a}$ & $77.33 \mathrm{a}$ & $15.13 \mathrm{a}$ & $28.73 \mathrm{a}$ & $28.60 \mathrm{a}$ \\
T4 = legowo 4:1 Full $(25 \times 12.5 \times 50) \mathrm{cm}$ & $35.13 \mathrm{a}$ & $67.87 \mathrm{a}$ & $80.07 \mathrm{a}$ & $14.87 \mathrm{a}$ & $23.07 \mathrm{a}$ & $27.67 \mathrm{a}$ \\
T5 = legowo 4:1 free space & $32.67 \mathrm{a}$ & $64.13 \mathrm{a}$ & $80.40 \mathrm{a}$ & $13.47 \mathrm{a}$ & $24.40 \mathrm{a}$ & $29.33 \mathrm{a}$ \\
$(25 \times 12.5 \times 50) \mathrm{cm}$ & $34.13 \mathrm{a}$ & $64.80 \mathrm{a}$ & $76.20 \mathrm{a}$ & $13.67 \mathrm{a}$ & $25.73 \mathrm{a}$ & $26.47 \mathrm{a}$ \\
T6 = legowo 6: $1(25 \times 12.5 \times 50) \mathrm{cm}$ & & & & & & \\
\hline
\end{tabular}

System of planting legowo 4:1 free space is a cropping pattern by simply providing additional plant inserts on both rows of edge plants with spacing of $25 \mathrm{~cm} \times 12.5 \mathrm{~cm} \times$ $50 \mathrm{~cm}$ will be obtained population of \pm 192.000 clumps/hectare plant with percentage increase only $\pm 20 \%$ compared pattern tegel $(25 \times 25) \mathrm{cm}$. Planting system jajar legowo 6: 1 which is the cropping pattern legowo with an entire line got crop inserts, with a spacing of $25 \times 12.5 \times 50 \mathrm{~cm}$ icultural science, Volume 1, Number 1, Page 1 - 8 | 3. 
then the plant population reached \pm 274000 clump/ha.

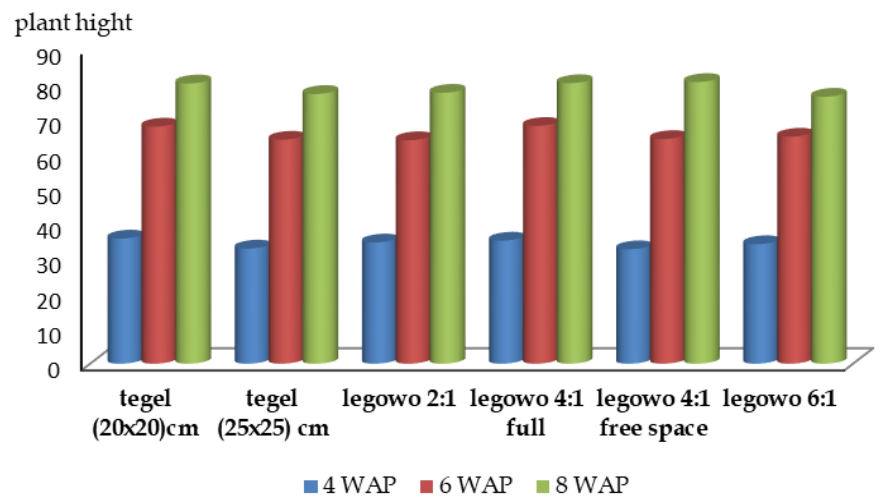

Figure 2 Plant Height of Ciherang Paddy Varieties on Various Treatments Planting System

Tegel planting system $(20 \times 20) \mathrm{cm}$; tegel $(25 \times 25) \mathrm{cm}$; jajar legowo 2: 1; legowo 4 : 1 full; jajar legowo 4: 1 free space and jajar legowo 6:1 did not give a significant effect on plant height and number of tillers for all observation period except at age 4 WAP (week after planting) for plant height (Table 2, Figure 2 and Figure 3). Spacing affects the number of plant populations. Based on Table 2, planting system jajar legowo 2:1; 4:1 full, 4:1 free space; 6:1 no causing an increase against the number of tillers, compare with system planting tegel 20 $\mathrm{cm} \times 20 \mathrm{~cm}$ and $25 \mathrm{~cm} \times 25 \mathrm{~cm}$. According Sumardi (2010) increase in plant population, negatively correlated to the total produced tillers, panicle number per unit area.

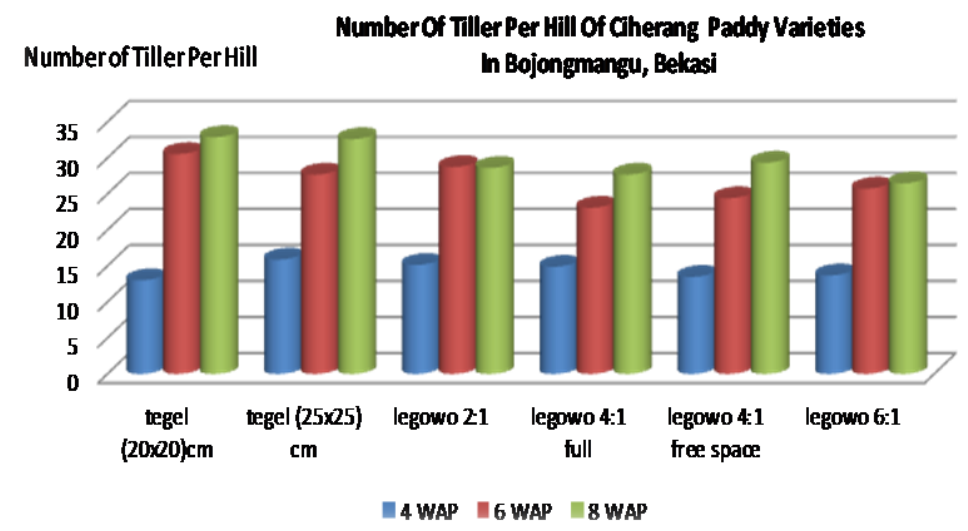

Figure 3 Number of Tiller per Clump of Ciherang Paddy Varieties on Various Treatments of Planting System

The more the number tillers per clump per unit area of the fewer number of tillers and productive tillers. Clump derived from treatment jajar legowo row 6: 1 shows the plant height and number of tillers at least. Early competition between leaf sheets is alleged to have lowered plant height and strong tillers (vigorous). Increasing the number of clumps per unit area tends to increase competition between plants in clumps and clumps other to light, space, and nutrients that affect growth and production. The number of tillers of tegel system gives the number of tillers per clump higher than the jajar legowo system. Tillers grown from the roots of paddy plants are divided into primary, secondary and tertiary tillers whose growth is determined by the surrounding environmental conditions, such as plant spacing, radiation, mineral nutrient, and cultivation techniques. This is in accordance 
with the statement of Yoshida (1981) in Makarim and Suhartatik (2009) states that not all buds will grow into tillers because it is determined by spacing, radiation, mineral nutrients and cultivation. According to Ikhwani et . al. (2013) that $\mathrm{p}$ there are some particular variety or decrease the number of tillers because the number of panicles in right clump that is too tight.

\section{Yields Component}

Table 3 and Figure 4 show that there are differences in the number of panicles per clump, number of grains per panicle, number of fully grains per panicle and weight of 1000 grains due to differences in spacing of the system. It is not obvious that the pattern of plant spacing type in tegel and jajar legowo, to the length of panicle because the length of panicle is only influenced by the variety (genetic factor) and not the environment.

According to Sumardi (2010), the increase in plant population per unit area is negatively correlated with the number of panicles per clump. The number of panicles per clump highly positive correlates with the number of grains per panicle and the weight of a thousand grains of grain. It shows the increasing number of panicles increasing the number of grains per panicle and the weight of a thousand grains. The number of panicles per clump, the number of grain per panicle and the weight of 1000 grains of the highest were obtained on the spacing pattern of legowo 2: 1 spacing followed by a full 4:1 legowo and 25 $\mathrm{cm} \times 25 \mathrm{~cm}$ tegel system. The jajar legowo planting system provides a different space for obtaining the sunlight used in photosynthesis. The more sunlight the plant can absorb the faster the process of photosynthesis takes place and ultimately accelerate plant growth. When the need for glucose is sufficient, the excess glucose is converted into carbohydrates and stored as food in the roots, stalks, and grains of rice. Planted paddy planted with full jajar legowo 4:1 planting system gives the number of panicles per clump, the number of grains per panicle and the weight of a thousand grains better than jajar legowo 4:1 free space because this full 4:1 legowo planting system is grown on a grain jelly of poor nutrient - grumusol soil that has a low $\mathrm{P}$ and $\mathrm{K}$ high element content and has ph 5.2. According to Sarlan et al (2013) that the jajar legowo planting system 4: 1 full compatible with the conditions of the infertile land.

\section{Table 3 The effect of plant spacing on yield component of Ciherang paddy varieties}

\begin{tabular}{|c|c|c|c|c|c|}
\hline Planting System & $\begin{array}{l}\text { The Number } \\
\text { of Panicle per } \\
\text { clump }\end{array}$ & $\begin{array}{l}\text { Long } \\
\text { Panicle }\end{array}$ & $\begin{array}{c}\text { The Number } \\
\text { of Grain per } \\
\text { panicle }\end{array}$ & $\begin{array}{l}\text { The Number } \\
\text { of Full Grains } \\
\text { per panicle }\end{array}$ & $\begin{array}{l}\text { Weight of } \\
1000 \text { Grains } \\
\text { (g) }\end{array}$ \\
\hline $\mathrm{T} 1=$ tegel $(20 \times 20) \mathrm{cm}$ & $12.53 \mathrm{a}$ & $25.00 \mathrm{a}$ & $136.00 \mathrm{a}$ & $116.93 \mathrm{~b}$ & $23.33 \mathrm{a}$ \\
\hline $\mathrm{T} 2=$ tegel $(25 \times 25) \mathrm{cm}$ & $14.80 \mathrm{~b}$ & $25.60 \mathrm{a}$ & $141.00 \mathrm{a}$ & $132.06 \mathrm{c}$ & $24.16 \mathrm{c}$ \\
\hline $\begin{aligned} \mathrm{T} 3= & \text { legowo 2: } 1 \\
& (25 \times 12,5 \times 50) \mathrm{cm}\end{aligned}$ & $17.13 \mathrm{c}$ & $25.40 \mathrm{a}$ & $158.13 \mathrm{~b}$ & $129.46 \mathrm{bc}$ & $25.33 c$ \\
\hline $\begin{aligned} \mathrm{T} 4= & \text { legowo } 4: 1 \text { full } \\
& (25 \times 12,5 \times 50) \mathrm{cm}\end{aligned}$ & $15.06 \mathrm{c}$ & $25.87 \mathrm{a}$ & $152.60 \mathrm{a}$ & $111.86 \mathrm{a}$ & $24.13 \mathrm{bc}$ \\
\hline $\begin{aligned} \mathrm{T} 5= & \text { legowo } 4: 1 \text { free space } \\
& (25 \times 12,5 \times 50) \mathrm{cm}\end{aligned}$ & $11.89 \mathrm{a}$ & $25.60 \mathrm{a}$ & $131.93 \mathrm{a}$ & $115.06 \mathrm{~b}$ & $19.33 \mathrm{a}$ \\
\hline $\begin{aligned} \mathrm{T} 6= & \text { legowo 6: } 1 \\
& (25 \times 12,5 \times 50) \mathrm{cm}\end{aligned}$ & $12.06 \mathrm{a}$ & $25.26 \mathrm{a}$ & $129.26 \mathrm{a}$ & $106.2 \mathrm{a}$ & $19.76 \mathrm{a}$ \\
\hline
\end{tabular}

The number of fully grains per panicle is not significantly correlated with the number of grain per panicle. According to Darwis (1982), that the more of grain formed then the heavier the burden of plants to form the loaded grains. Matsushima (1975) in Sugiono and Saputro (2016) stated that there are several factors causing a decrease in percentage of 
grain contents: (1) increasing number of grains per panicle, (2) increasing number of unproductive caryopsis and (3) low starch content (photosynthesis) in the vegetative organs before the flowering period.

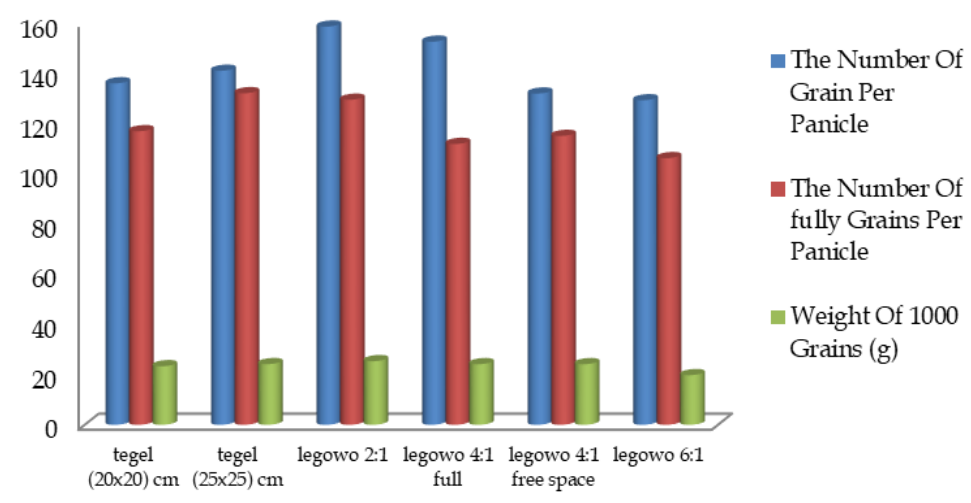

Figure 4. Yield Component of Ciherang Paddy Varieties on Various Treatment Planting System

\section{The Yield Per plot}

Yield per plot of Ciherang paddy varieties on various planting system treatments showed on Table 4 and Figure 5. The system spacing legowo 2:1 yielded the highest average yield of $6.23 \mathrm{~kg} /$ plot equal to 9,968 ton/ha. It was followed by full 4:1 legowo spacing which reached $6.15 \mathrm{~kg} /$ plot equivalent to 9,840 tons/h. On average, both cropping systems produced paddy per hectare higher than the 20 $\mathrm{cm} \times 20 \mathrm{~cm}$ tegel system which yields an average of $5.41 \mathrm{~kg}$ or equivalent to 8.565 tons/ha and $25 \mathrm{~cm} \times 25 \mathrm{~cm}$ tegel system which produces an average $5.95 \mathrm{~kg}$ or equivalent 9.520 tons/ha.

Table 4 The effect of plant spacing on average of the yield of Ciherang paddy varieties

\begin{tabular}{lcc}
\hline \multicolumn{1}{c}{ Planting System $(\mathrm{cm})$} & $\begin{array}{c}\text { Yield per Plot } \\
(\mathrm{kg} \text { DGH })\end{array}$ & $\begin{array}{c}\text { Average yield per } \\
\text { hectare }(\mathrm{kg} \text { DGH })\end{array}$ \\
\hline T1 $=$ tegel $(20 \times 20) \mathrm{cm}$ & $5.41 \mathrm{~b}$ & $8565 \mathrm{a}$ \\
T2 $=$ tegel $(25 \times 25)$ & $5.95 \mathrm{bc}$ & $9520 \mathrm{a}$ \\
T3 $=$ legowo $2: 1(25 \times 12.5 \times 50) \mathrm{cm}$ & $6.23 \mathrm{~cd}$ & $9968 \mathrm{a}$ \\
T4 $=$ legowo $4: 1$ Full $(25 \times 12.5 \times 50) \mathrm{cm}$ & $6.15 \mathrm{c}$ & $9840 \mathrm{a}$ \\
T5 $=$ legowo $4: 1$ free space $(25 \times 12.5 \times 50) \mathrm{cm}$ & $5.05 \mathrm{a}$ & $8080 \mathrm{a}$ \\
T6 $=$ legowo 6: $1(25 \times 12.5 \times 50) \mathrm{cm}$ & $4.85 \mathrm{a}$ & $7760 \mathrm{a}$ \\
\hline
\end{tabular}

The legowo row planting system in the direction of the outer crop line provides a relaxed growing space as well as a higher population. In addition, this planting system is able to provide a better air circulation and utilization of sunlight for cropping. The more intensity of sunlight, then, the process of metabolism, especially photosynthesis of plants that occur in the leaves will be higher. It results good quality of the plant. The reseach also found that the lowest yield was obtained from the planting distance treatment of legowo 6:1 which only reached $4.85 \mathrm{~kg} /$ plot or equivalent 7.760 ton/ha. 


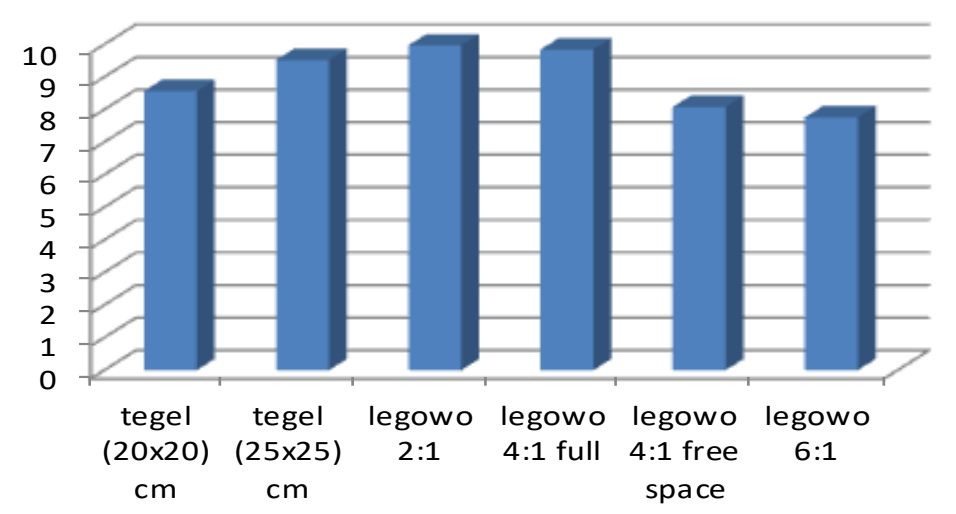

Figure 5 Yield (tons/ha) Ciherang Paddy Varieties on various planting system treatments

\section{CONCLUSION}

The use of the 2: 1 jajar legowo planting system provides the highest of the number of panicles per clump, the number of grains per panicle, the weight of 1000 grains and yield per hectare, followed by a full 4:1 jajar legowo planting system. Further studies are needed on different paddy planting systems, different varieties and combinations with fertilizer treatment or others.

\section{REFERENCES}

Anonim, 2018. Teknologi Budidaya Paddy dengan Cara Tanam Legowo pada Lahan Sawah Irigasi. Sukamandi; Balibangtanpang. Balai penelitian dan Pengembangan Pertanian.http/www.blog spot. Diakses 06/01/ 2018

Anonim, 2018. Pedoman Penerapan Teknologi terhadap tanaman paddy Varietas Ciherang Sukamandi; Balibangtanpang Balai penelitian dan Pengembangan Pertanian Accessed from http:// deptan.go.id/ditlinpangan/publikasi. htm at 06 January 2018.

Darwis, 1982. Efisiensi Pemupukan Nitrogen Terhadap Paddy Sawah Pada Berbagai Lokasi. Agroklimat. Desertasi Doktor, Fakultas Pasca Sarjana Institut Pertanian Bogor.

Darmawan, M., 2016. Analysis of Legowo Row Planting System and System of Rice Intensification (SRI) of Paddy Field
(Oryza Sativa L.) Toward Growth and Production. Agrotech J. 1, 14-18.

Guswara. 2013. Sistem Tanam Legowo. Badan Penelitian dan Pengembangan Pertanian. Kementrian Pertanian. Retrieved at 1 April 2018 from http// dogs.google.com/viewerng/vie wer?url=http://litbang.pertanian.go.i d/images

Hatta, M., 2012. Uji Jarak Tanam Sistem Legowo terhadap Pertumbuhan dan Hasil Beberapa Varietas Paddy Pada Metode SRI. J. Agrista 16, 87-93

Ikhwan, Gagad R.P.; Eman P. dan A.K. Makarim. 2013. Peningkatan Produktivitas Paddy Melalui Penerapan Jarak Tanam Jajar Legowo. IPTEK Tanaman Pangan 8(2):11-24. Retrieved at 30 April 2018 from htp://www.pangan.litbang.pertanian. go.id

Karokaro, S., Rogi, J.E.X., Runtunuwu, D.S., Tumewu, P., 2015. Pengaturan Jarak Tanam Paddy (Oryza Sativa L.) pada Sistem Tanam Jajar Legowo. Cocos 6: $1-7$.

Kusyaeri, K., Dan, H., Murtiani, S., Pengkajian, B., Pertanian, T., Barat, J., 2014. APLIKASI Sistem Tanam Jajar Legowo Untuk Meningkatkan Produktivitas Paddy Sawah Application of Jajar Legowo Planting System To Increase Paddy Yield. Agros 16, 285-291. 
Makarim K. dan E. Suhartati. 2009. Morfologi dan Fisiologi Tanaman Paddy. Balai Besar Penelitian Tanaman Paddy. Sukamandi, Subang Retrieved at 30 April 2018 from http:/ / litbang.pertanian.go.id

Masdar, S. 2013. Teknologi Budidaya Paddy dengan Cara Tanam Legowo pada Lahan Sawah Irigasi. Sukamandi; Balibangtanpang. Balai penelitian dan Pengembangan Pertanian.

Meas, V., Shon, D., Lee, Y.H., 2011. Impacts of Planting Density on Nutrients Uptake by System of Rice Intensification under No-tillage Paddy in Korea. 한국토양비료학회지 - Korean J. Soil Fertil. 44, 98-103.

Mulyati, S., Rochdiani, D., Yusuf, M.N., 2017. Pengaruh Faktor Sosial Ekonomi Petani dan Partisipasi Petani dalam Penerapan Teknologi Pola Tanam Paddy (Oryza sativa L) Jajar Legowo 4:1. Agroinfo Galuh 3.

Sari, D.N., 2014. Pengujian Berbagai Tipe Tanam Jajar Legowo terhadap Hasil Paddy Sawah. Akta Agrosia. 17, 115124.

Sari, F.M. 2018. Impor 500 ribu Ton Beras Tak Efektif, Kenapa. https://www.liputan6.com/bisnis / read/3358743/impor-500-ributon-beras-tak-efektif-kenapa. accessed at 4 May 2018.
Sarlan, A, Made Jana Mejaya, Nurwulan Agustiani, Indra Gunawan, Priatna Sasmita, Agus Guswara. 2013. Sistem Tanam Legowo. Accessed from https://docs.google.com/viewerng/v iewer?url

=http://bbpaddy.litbang.pertanian.go .id/images/publikasi/panduanteknis/Sistem-Tanam-LEGOWO.pdf. 25 April 2018.

Suhartatik, E., A.K. Makarim, dan Ikhwani. 2013. Respon Lima Varietas Unggul Baru terhadap Perubahan Jarak Tanam. Inovasi Teknologi Paddy Mengantisipasi Cekaman Lingkungan Biotik dan Abiotik. Prosiding Seminar Nasional Hasil Penelitian Paddy 2011, pp. 1259-1273.

Sugiono D. dan N.W.W Saputro. 2016. Respon Pertumbuhan dan hasil Beberapa Genotipe Paddy (Oryza sativa L.) Pada Berbagai Sistem ranam. Retrieved from

https://journal.unsika.ac.id/index.ph p/agrotek/view/341

Sumardi S. 2010. Produktivitas Paddy Sawah Kepadatan Populasi yang Berbeda. Jurnal Ilmu-ilmu Pertanian Indonesia. Retrieved at 1 May 2018 from https://www. repository.unib.ac.id

Yoshida, S. 1981. Fundamental of Rice Crop Science. International Rice Research Institute. Los Barios, Laguna, Philipines. http:// www.scrip.org/.../reference/Referenc esPapers.aspx. 1 April 2018. 